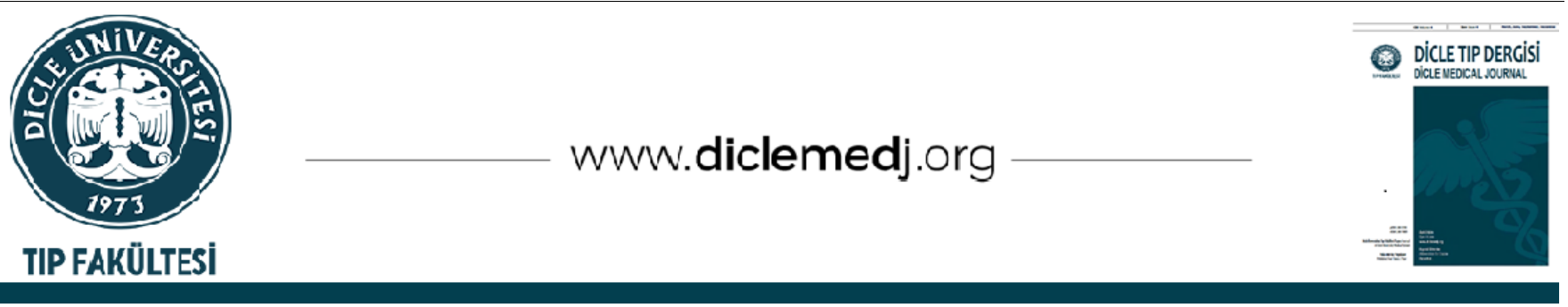

\title{
Çukurova Üniversitesi Tıp Fakültesi Adli Tıp Anabilim Dalı'na Hatalı Tıbbi Uygulama İddiası ile Başvuran Olguların Değerlendirilmesi (2015-2019)
}

\author{
Toygün Anıl Özesen ${ }^{1}$, Kenan Kaya ${ }_{1}$ \\ 1 Çukurova Üniversitesi, Tıp Fakültesi, Adli Tıp Anabilim Dalı Adana, Türkiye
}

Geliș: 24.03.2021; Revizyon: 26.10.2021; Kabul Tarihi: 10.11.2021

Öz

Giriș: Tıbbi uygulama hatası ile ilgili davaların görülme sıklığı tüm dünyada olduğu gibi ülkemizde de artış göstermektedir. Sağlık çalışanları bu davaların sonucunda cezai yaptırımla birlikte yüksek miktarlarda tazminat ödemeye mahkûm olabilmektedirler. Bu çalışma ile dosyaların özellikleri, bu iddialar ile karşılaşılan hekimler ve bu konuyla ilgili rapor düzenleyen hekimlere bilgi vermek amaçlanmıștır.

Yöntemler: Ocak 2015 ile Aralık 2019 tarihleri arasında Çukurova Üniversitesi Tıp Fakültesi Adli Tıp Anabilim Dalına hatalı tıbbi uygulama iddiasına ilişkin başvuru sonrası değerlendirmelerde bulunarak rapor düzenlenen 37 dosya retrospektif olarak incelenmiştir.

Bulgular: Hatalı tıbbi uygulama iddiasıyla şikayette bulunulan sağlık personellerinin 48'inin doktor, 3'ünün hemşire, 1'inin yardımcı sağlık personeli olduğu saptandı. Aynı dosya içerisinde birden çok hekim ve sağlık personeli hakkında şikayette bulunulduğu \%15 (n=7) ile en sık pratisyen hekimlerin șikayet edilmiş olduğu tespit edilmiștir. Dosyaların \%48,6'sının (n=18) ölümlü olgular ile ilișkili olduğu, bu olguların \%38,8'ine (n=7) otopsi işleminin gerçekleştirilmiş olduğu tespit edilmiştir. Dosyaların hatalı tıbbi uygulama iddiasına ilişkin değerlendirilme sonuçlarında kusur durumuna göre inceleme yapıldığında, dosyaların \%10,8'inde (n=4) tıbbi uygulama kusuru olduğu kanaatine varıldığı, bu dosyaların \%50’sinin (n=2) Mahkeme (Ağır Ceza Mahkemesi, Asliye Hukuk Mahkemesi, Asliye Ticaret Mahkemesi) makamı, \%25'inin (n=1) Cumhuriyet Savcılığı makamı, \%25'inin ise bireysel bașvuru (n=1) ile değerlendirilmiș olduğu saptandı. Tıbbi uygulama kusurunun olmadığı kanaatine varılan dosyaların ise \%66,6'sının ( $n=22)$ bireysel başvuru, \%18,1'inin ( $n=6)$ Mahkeme, \%12,1'inin ( $n=4)$ Cumhuriyet Savcılığı makamlarınca değerlendirilmek üzere yönlendirilmiş olduğu tespit edilmiştir. Mevcut dosyaların içerisinde bulunan ifade tutanakları incelendiğinde, \%29,7'sinde (n=11) hekim ile hasta ve/veya yakınlarının tartışma yaşamış olduğu tespit edilmiştir.

Tartışma: Hatalı tıbbi uygulamalarına ilişkin iddialar gün geçtikçe artmakta hasta veya yakınları istenen sonucun ortaya çıkmadığı durumlarda şikayetçi olmaktadır. Hekimlere yönelik şikayetlerin artmasının defansif tıp uygulamalarını arttırdığı, bunun hem hastanın tanıtedavisini geciktirdiği hem de sağlı sistemi üzerinde yük oluşturduğu unutulmamalıdır. Hatalı tıbbi uygulama iddialarını en aza indirmek için sağlık çalışanlarının mesleki bilgi ve tecrübelerini geliștirmek dışında iyi bir hekim hasta iletişimi kurmaları gerekmektedir.

Sonuç: Ölümün gerçekleştiği olgularda ölüm sebebinin belirlenmesi için otopsi yapılması sağlık çalışanlarının kusurunun olup olmadığını belirlemek konusunda oldukça önemli olduğundan, hatalı tıbbi uygulama şüphesi/şikâyeti olan tüm ölüm olgularında otopsi yapılması tıbbi uygulama hatasının varlığının tespiti konusunda oldukça önem arz etmektedir.

Anahtar kelimeler: "Tıbbi Uygulama Hatası", "Hekim", "Otopsi”, 'Tıbbi Komplikasyon"

DOI: $10.5798 /$ dicletip.1037820

Yazışma Adresi / Correspondence: Toygün Anıl Özesen, Çukurova Üniversitesi Tıp Fakültesi Balcalı Hastanesi, Adli Tıp Anabilim Dalı, Adana, Türkiye email: toygunanilozesen@gmail.com 


\title{
Evaluation of Cases Applied To Cukurova University Medicine Faculty Forensic Medicine Department With Alleged Faulty Medical Application (2015-2019)
}

\begin{abstract}
Objective: The incidence of cases related to medical malpractice is increasing in our country as well as in the rest of the world. As a result of these lawsuits, healthcare workers may be sentenced to pay high amounts of compensation along with criminal sanctions. With this study, it is aimed to inform the characteristics of the files, the physicians who encountered these claims and the physicians who prepared a report on this subject.

Method: Between January 2015 and December 2019, 37 files for which reports were prepared after the application to the Çukurova University Faculty of Medicine, Department of Forensic Medicine regarding the alleged malpractice were examined retrospectively.

Results: It has been determined that 48 of the health personnel who were complained about medical malpractice were doctors, 3 were nurses, and 1 were assistant health personnel. It was observed that the most common complaints were made by general practitioners. It was determined that $48.6 \%(\mathrm{n}=18)$ of the files were related to mortal cases, and autopsy was performed in $38.8 \%$ ( $\mathrm{n}=7$ ) of these cases. When the results of the evaluation of the files regarding the alleged malpractice are examined, it is concluded that $10.8 \%(\mathrm{n}=4)$ of the files have a medical malpractice, $50 \%(n=2)$ of these files are submitted to the Court, $25 \%(n=1)$ to the Prosecutor's Office and $25 \%(n=1)$ to the private application. It was determined that $66.6 \%(n=22)$ of the files were evaluated by the private application, $18.1 \%(n=6)$ by the court and $12.1 \%(n=4)$ by the Prosecutor's Office. When the transcripts in the existing files were examined, it was determined that $29.7 \%(\mathrm{n}=11)$ of them had a discussion with the physician, the patient and/or their relatives.

Discussion: Claims regarding medical malpractice are increasing day by day, and patients or their relatives complain when the desired result is not achieved. It should not be forgotten that the increase in complaints against physicians increases the practice of defensive medicine, which both delays the diagnosis and treatment of the patient and creates a burden on the health system. In order to minimize the claims of malpractice, healthcare professionals need to establish good doctor-patient communication apart from improving their professional knowledge and experience.

Conclusion: Since autopsy is very important in determining the cause of death in cases where death has occurred, it is very important to determine whether there is a fault of the health care workers, so autopsy is very important in determining the presence of medical malpractice in all cases of death with suspicion/complaints of malpractice.
\end{abstract}

Keywords: "Medical Malpractice", "Medical Physician", "Autopsy", "Medical Complication"

\section{GíRiş}

Tıbbi müdahale; kişinin bedensel, fiziksel ya da ruhsal bir hastalığını teșhis ve tedavi etmek, hastalı̆̆ını hafifletmek ya da hastalıktan korumak ya da nüfus planlaması amacıyla tıp mesleğini icraya hukuken yetkili kişiler tarafından tıp bilimince kabul görmüş esaslara uygun olacak şekilde gerçekleștirilen her türlü faaliyet olarak tanımlanabilir. Tibbi müdahalenin hukuka uygun gerçekleştirilmesi bazı şartlara bağlıdır. Bunlar; tıbbi müdahalenin hukuken yetkili kişiler tarafından yasalara uygun olarak gerçekleștirilmesi, tıbbi müdahalenin tıp biliminin kural ve standartlarina uygun olmasl, tıbbi zorunluluk/gereklilik "endikasyon" olması ve kişinin aydınlatılmış rızasının alınmasıdır ${ }^{1}$.

Malpraktis kelimesi Latince "mala" ve "praxis" kelimelerinden köken almış olup, mesleki uygulamalar sırasında beceri veya özen eksikliğinden kaynaklanan tüm kusurlu eylemleri tanımlamak için kullanılmaktadır. Malpraktis kelimesi genel bir kavram olup, tıp alanı ile alakalı kusurlu eylemlerin "tıbbi malpraktis" veya "tıbbi uygulama hatası" olarak belirtilmesi uygun olacaktır. Tibbi malpraktis, hekimlerin tıbbi bir girișim, tedavi ya da uygulamayı güncel ve genel kabul görmüş standartlar çerçevesinde yapmaması, ortalama tıbbi bilgi, beceri, dikkat ve özene sahip bir hekimden beklenen performansı gösterememesi sonucu hizmet alan kişinin zarar görmesi durumu olup, sağllk hizmetlerinin herhangi bir aşamasında ortaya çlkabilmektedir².

Tıbbi uygulama hataları son yıllarda tüm dünyada etik, hukuki ve tıbbi yönlerden tartışılan bir konu olsa da tıbbi malpraktis kavramının gündeme gelişi çok eskilere dayanmaktadır. İlk defa 1374 yılında, 
İngiltere'de görülen Stratton v. Swanlond davasında tıbbi hatadan bahsedilmiştir. Davaya konu olay; Stratton isimli cerrahın, eli ezilen Swanlond isimli hastasıyla ücret karşıllğ elindeki hasarı düzelteceğine dair sözleşme yapması, ancak uyguladığı tedavi sonrası hastasının elinde kalıcı ve ağır deformiteler meydana gelmesi, bunun üzerine hastanın ve eşinin doktorun sözleşmeye uymadığ iddiasından ibarettir. Mahkeme başkanı John Cavendish kararında; hekimin kendi hatasından dolayı hastaya zarar vermesi durumunda sorumlu olacağı, ancak tedavide özen gösterilmesine rağmen başarılı sonuç elde edilemezse hekimin sorumluluğunun doğmayacağı şeklinde görüş bildirmiş, böylece bu dava tıbbi hatalı uygulamanın ve hekim sorumluluğunun genel kriterleri açısından önem kazanmıştır. Sonraki yıllarda benzer davalar görülmeye devam etse de malpraktis terimi ilk olarak Sir William Blackstone tarafından 1768 yılında yayımlanan "Commentaries on the Laws of England (İngiltere Kanunlarına İlişkin Yorumlar)" adlı eserde, tıp uygulamalarındaki ihmalleri tanımlamaya yönelik kullanılmıştır ${ }^{3}$.

Tıbbi standart, benzer ortam koşullarında, tıp biliminin genel olarak kabul görmüş veya denenerek ispatlanmış kuralları çerçevesinde, ortalama bilgi ve beceriye sahip hekimden beklenen özen şeklinde tanımlanmaktadır. Hekimin görev yaptığı yer ve bu standartlara ulaşabilme olanağı da tıbbi standardın belirlenmesinde rol oynamaktadır ${ }^{4}$.

Komplikasyon, bir hastalığın seyri veya tedavisi sırasında ortaya çıkabilen, hastalığın kendinden ya da tıbbi müdahaleden kaynaklanan, tıbbın kabul ettiği normal risk ve sapmalar dahilinde gerçekleşebilen, öngörülemeyen, öngörülse dahi önlenemeyen her türlü olumsuz sonuçlar olup, bu duruma hukuk terminolojisinde "izin verilen risk" denilmektedir. Hekim müdahalesinin tıbbi standartlara uygun olması ve müdahale öncesi komplikasyon konusunda hastasını bilgilendirip rızasını alması halinde, ortaya çıkan komplikasyonlardan dolayı hekim sorumlu tutulmazken, komplikasyonların zamanında fark edilmemesi, fark edilmesine rağmen önlem alınmaması ve alınan önlemlerin tıbbi standartlara uygun olmaması sonucu hekim sorumluluğu gündeme gelecektir ${ }^{5,6}$.

Tıbbi uygulama hatası ile ilgili davaların görülme sıklığı tüm dünyada olduğu gibi ülkemizde de artış göstermektedir 7. Sağlık çalışanları bu davaların sonucunda cezai yaptırımla birlikte yüksek miktarlarda tazminat ödemeye mahkûm olabilmektedirler. $\mathrm{Bu}$ çalışmada Çukurova Üniversitesi Tıp Fakültesi Adli Tıp Anabilim Dalı'na Ocak 2015- Aralık 2019 tarihleri arasında Mahkeme, Cumhuriyet Savcllı̆̆g, il sağlık müdürlüğü ve bireysel olarak gönderilen/başvuran hatalı tıbbi uygulama iddiası olgularına ilişkin düzenlenen raporlar incelenerek dosyaların özellikleri, bu konularla ilişkili rapor düzenleyen ve bu durumla karşılaşan hekimlerin dikkat etmesi gereken hususlar konusunda bilgi vermek amaçlanmıştır.

\section{YÖNTEMLER}

Ocak 2015-Aralık 2019 tarihleri arasında Çukurova Üniversitesi Tıp Fakültesi Adli Tıp Anabilim Dalına hatalı tıbbi uygulama iddiasına ilişkin başvuru sonrası değerlendirmelerde bulunarak rapor düzenlenen 37 dosya retrospektif olarak incelenmiştir.

Veriler kayıt altına alınırken; şikâyet edilen hekimlerin uzmanlık alanı, ölüm oranı, otopsi oranı, olay tarihi, mütalaa tarihi, kusur durumu, aydınlatılmış onam alınma oranı, hasta-hekim arasında tartışma olup olmadığı, hekimin hangi yükümlülükleriyle ilgili iddia olduğu, bireysel başvuru ve mahkeme başvuruları değerlendirme kriterleri olarak seçilmiştir.

Bu çalışma için 22 Ocak 2021 tarih ve 107 Sayılı T.C. Çukurova Üniversitesi Tip Fakültesi Girişimsel Olmayan Klinik Araştırmalar Etik Kurulu Toplantısında Etik Yönden Uygun 
olduğuna dair 10 Karar Numarası ile onay alınmıştır.

Toplanan veriler SPSS 20.0 (Statistical Package for Social Science) programına yüklenerek verilerin analizi ve karşılaştırmalı olarak değerlendirilmesi yapılmıștır. Bulgular tablo ve grafiklerle gösterilerek olguların özellikleri incelenmiștir.

\section{BULGULAR}

Ocak 2015-Aralık 2019 tarihleri arasında Çukurova Üniversitesi Tıp Fakültesi Adli Tıp Anabilim Dalına hatalı tıbbi uygulama iddiasına

Tablo I: Yıllara göre görüş isteyen merci ve dosya sayıları ilișkin bașvuru sonrası değerlendirmelerde bulunarak rapor düzenlenen 37 dosya retrospektif olarak incelenmiştir. Dosyalardan 8'inin Mahkeme, 5'inin Cumhuriyet Savcllığı, 1'inin il sağlık müdürlüğü, 23'ünün bireysel başvuru yoluyla değerlendirilmek üzere yönlendirilmiş olduğu tespit edilmiștir.

Değerlendirilen dosyaların yıllara göre dağılımında; en fazla dosyanın (12 dosya) 2018 yllında değerlendirildiği, bunu 9 dosya ile 2019 yılının takip ettiği tespit edilmiștir. Yıllara göre tarafımızdan görüş isteyen mercii ve dosya sayıları Tablo-1'de gösterilmiştir.

\begin{tabular}{|c|c|c|c|c|c|c|c|c|c|c|c|c|}
\hline \multirow{3}{*}{$\begin{array}{c}\text { Görüş İsteyen } \\
\text { Merci }\end{array}$} & \multicolumn{10}{|c|}{ YII } & \multirow{2}{*}{\multicolumn{2}{|c|}{ Toplam }} \\
\hline & \multicolumn{2}{|c|}{2015} & \multicolumn{2}{|c|}{2016} & \multicolumn{2}{|c|}{2017} & \multicolumn{2}{|c|}{2018} & \multicolumn{2}{|c|}{2019} & & \\
\hline & $\begin{array}{c}\text { Dosya } \\
\text { Sayısı (n) }\end{array}$ & Oran \% & $\begin{array}{c}\text { Dosya } \\
\text { Sayısı (n) }\end{array}$ & Oran \% & $\begin{array}{c}\text { Dosya } \\
\text { Sayısı (n) }\end{array}$ & Oran \% & $\begin{array}{c}\text { Dosya } \\
\text { Sayısı (n) }\end{array}$ & Oran \% & $\begin{array}{c}\text { Dosya } \\
\text { Sayısı (n) }\end{array}$ & Oran \% & $\begin{array}{c}\text { Dosya } \\
\text { Sayısı (n) }\end{array}$ & Oran \% \\
\hline Bireysel Başvuru & 4 & 10.8 & 5 & 13.5 & 1 & 2.70 & 8 & 21.6 & 5 & 13.5 & 23 & 62.1 \\
\hline Mahkeme & 0 & 0 & 0 & 0 & 4 & 10.8 & 2 & 5.40 & 2 & 5.40 & 8 & 21.6 \\
\hline $\begin{array}{c}\text { Cumhuriyet } \\
\text { Savcılığı }\end{array}$ & 1 & 2.70 & 1 & 2.70 & 0 & 0 & 2 & 5.40 & 1 & 2.70 & 5 & 13.5 \\
\hline $\begin{array}{c}\text { ill Sağlık } \\
\text { Müdürlüğü }\end{array}$ & 0 & 0 & 0 & 0 & 0 & 0 & 0 & 0 & 1 & 2.70 & 1 & 2.70 \\
\hline Toplam & 5 & 13.5 & 6 & 16.2 & 5 & 13.5 & 12 & 32.4 & 9 & 24.3 & 37 & 100 \\
\hline
\end{tabular}

Dava açlan hekimlerin branşları incelendiğinde, en sik pratisyen hekimlere (\%15.9) dava açılmış olduğu, ancak hekimlik branşları dahili ve cerrahi bilimler olarak ayrım yapılarak incelendiğinde \%61,36 oranla en sık cerrahi bilimler branşında hatalı tıbbi uygulama iddiasıyla başvuru olduğu, cerrahi branş içerisinde ise en sık Kadın Doğum ve Genel Cerrahi branşıyla ilişkili başvuru olduğu, 3 dosyada hemşirelerin, 1 dosyada sağllk kuruluşunun servis şoförünün de şikayet edildiği, 4 dosyada hem hekim hem sağlık personelleriyle ilgili iddia olduğu, 5 dosyada ise birden fazla hekim branşıyla ilgili iddia olduğu tespit edilmiştir. Değerlendirilen dosyalarda ki hekim branşlarının dağılımı Grafik-1'de gösterilmiștir.
Hatalı tıbbi uygulama iddiası bulunan sağlık hizmeti ile görüş için tarafımıza başvuru arasında geçen süre incelendiğinde; mütalaa ile olay tarihi arasında ortalama 28 ay süre olduğu, en uzun süre olarak 11 yıl sonra görüşümüze başvurulduğu, başvuruyu yapan mercilere göre incelendiğinde ise, bireysel (özel) ve Cumhuriyet Savcllığı başvuruların ortalama 2 yıl içerisinde, Mahkeme başvurularının ise ortalama 4 yll içerisinde olduğu tespit edilmiştir.

Tıbbi müdahale sonrası meydana gelen durumlara göre inceleme yapıldığında, 37 dosyadan 18'inin ölümlü olduğu, ölümlü olmayan 19 dosyadan 6'sinda duyulardan veya organlardan birinin işlevinde sürekli zayıflama ya da yitirilme meydana gelmiş olduğu tespit edilmiştir. 


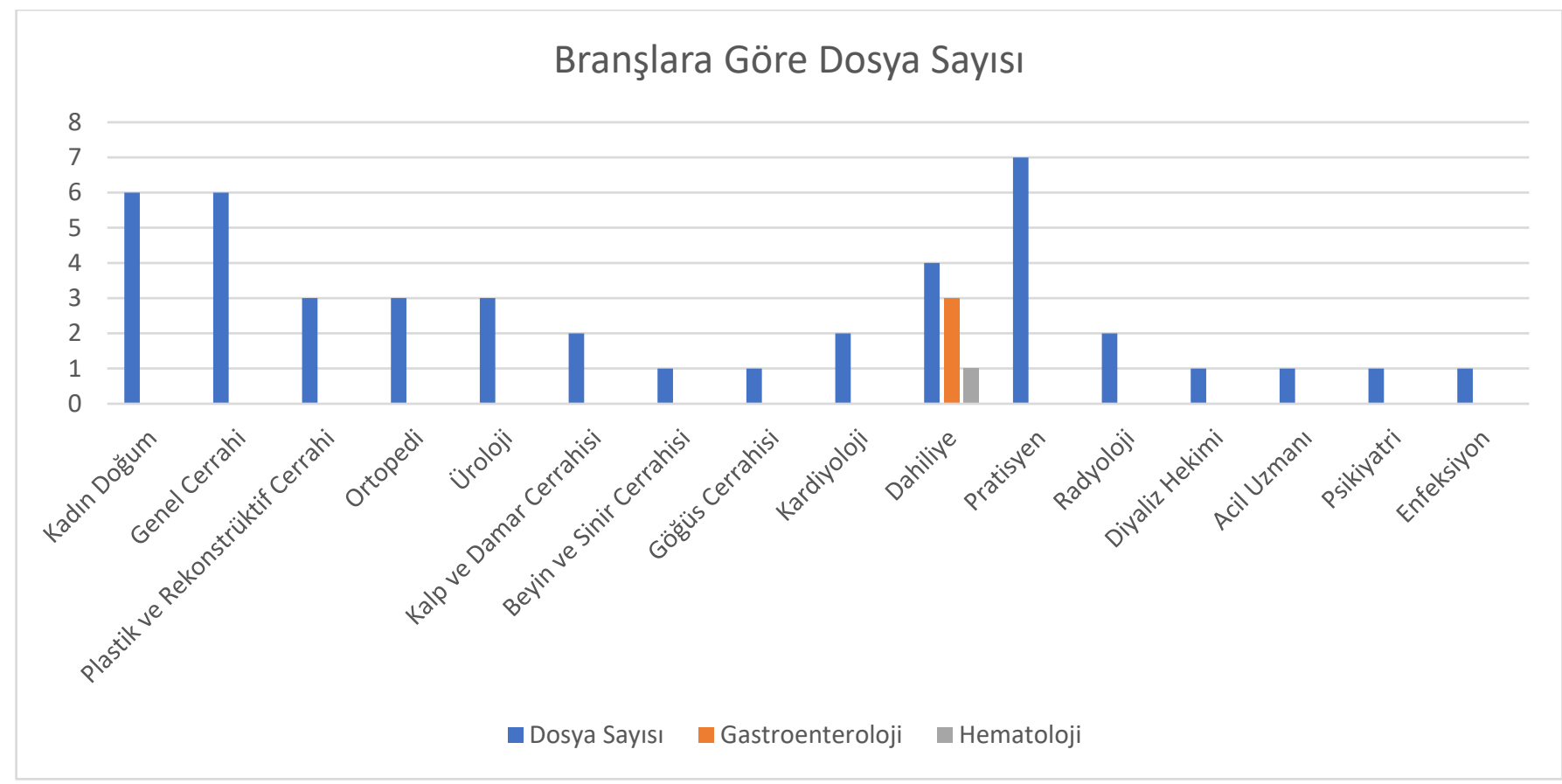

Grafik 1: Değerlendirilen dosyalarda ki hekim branşlarının dağılımı

Ölümlü dosyalarda otopsi durumu hekim kusuru olmadığı şeklinde görüş incelendiğinde ise 18 ölümlü dosyanın 11'inde bildirilmiş olduğu tespit edilmiştir. Dosyalarda otopsi işleminin gerçekleştirilmiş olduğu, ki ölüm durumu, otopsi işleminin otopsi işlemi yapılmış olan 7 dosyadan 6'sında gerçekleştirilme durumu ve hekim kusuruna ilişkin bilgiler Tablo-2'de gösterilmiştir.

Tablo II: Ölüm, Otopsi işlemi, Duyulardan veya Organlardan Birinin İşlevinde Sürekli Zayıflama ya da Yitirilme durumları ve Hekim kusuru konusunda verilen görüşler

\begin{tabular}{|c|c|c|c|c|c|c|c|c|c|c|}
\hline \multirow{5}{*}{$\begin{array}{l}\text { Kusur } \\
\text { Durumu }\end{array}$} & \multicolumn{8}{|c|}{ Tıbbi Uygulama Gerçekleştirilen Kişinin Ölüm Durumu } & \multirow{4}{*}{\multicolumn{2}{|c|}{ Toplam }} \\
\hline & & Ölü & १süz & & & & & & & \\
\hline & \multicolumn{4}{|c|}{$\begin{array}{c}\text { Duyulardan veya Organlardan Birinin İşlevinde Sürekli } \\
\text { Zayıflama ya da Yitirilme Durumu }\end{array}$} & \multicolumn{4}{|c|}{ Otopsi İşleminin Gerçekleştirilme Durumu } & & \\
\hline & \multicolumn{2}{|c|}{ Mevcut Değil } & \multicolumn{2}{|c|}{ Mevcut } & \multicolumn{2}{|c|}{ Otopsi Yapılmamış } & \multicolumn{2}{|c|}{ Otopsi Yapılmış } & & \\
\hline & Olgu Sayısı (n) & Oran \% & Olgu Sayısı (n) & Oran \% & Olgu Sayısı (n) & Oran \% & Olgu Sayısı (n) & Oran \% & Olgu Sayısı (n) & Oran \% \\
\hline Kusur Yok & 11 & 29.7 & 6 & 16.2 & 10 & 27.0 & 6 & 16.2 & 33 & 89.1 \\
\hline Toplam & 13 & 35.1 & 6 & 16.2 & 11 & 29.7 & 7 & 18.9 & 37 & 100 \\
\hline
\end{tabular}

Dosya içeriklerinde aydınlatılmış onam evraklarının durumlarına göre inceleme yapıldığında, 37 dosyadan 31'inde aydınlatılmış onamla ilgili herhangi bir evrak bulunmadığı, 5'inde aydınlatılmış onam evrakının bulunduğu, bu onamların uygun olduğu, 1'inde ise aydınlatılmıș onam alınmadan işlem gerçekleștirilmiş olduğu tespit edilmiştir.

Hasta-Hekim ilişkisinde ihlal edildiği iddia edilen yükümlülüklere göre inceleme yapıldı̆̆ında, 37 dosyadan 8'sinde 'Özen' konusunda, 7'sinde 'Tanı' konusunda, 1'inde 
'Tanı ve Özen' konusunda, 3'ünde 'Tanı-Tedavi' konusunda, 15'inde 'Tedavi' konusunda, 3'ünde 'Özen-Tedavi' konularında eksiklik olduğunun iddia edildiği tespit edilmiştir.

Dosya içeriklerinde mevcut ifade ve dilekçelerde, hasta-hekim ilişkisinde tartışma olup olmadığı incelendiğinde, 37 dosyadan \%29,7'sinde $(n=11)$ hasta-hekim arasinda tartışma olduğu, bu dosyalardan 10'unda hekim kusuru olmadığı, 1 dosyada hekim kusuru olduğu șeklinde görüș bildirilmiş olduğu tespit edilmiştir.

Hatalı tıbbi uygulama iddiasına ilişkin olarak görüş bildirilen, 37 dosyadan 4'ünde gerçekleştirilen tıbbi uygulamalarda kusuru olduğu, 33'ünde kusur olmadığı şeklinde görüş bildirilmiş olduğu tespit edilmiştir. Gerçekleştirilen tıbbi uygulamada kusur olduğu şeklinde görüş bildirilen dosyalardan 2'sinin Mahkeme, 1'inin Cumhuriyet Savcllı̆̆ bireysel (özel) başvuru şeklinde değerlendirilmek üzere yönlendirilmiş olduğu tespit edilmiştir.

Hatalı tıbbi uygulama iddiasına ilişkin olarak yapılan değerlendirmeler sonucunda, gerçekleştirilen tıbbi uygulamanın kusurlu olduğu şeklinde görüş bildirilen 4 dosyada ki hekim branşlarına göre inceleme yapıldığında, 2'sinin Kadın Doğum, 1'inin Ortopedi, 1'inin Pratisyen branşlarından olduğu tespit edilmiştir.

\section{TARTIŞMA}

Tıbbi müdahale; kişinin bedensel, fiziksel ya da ruhsal bir hastalığını teşhis ve tedavi etmek, hastalığını hafifletmek ya da hastalıktan korumak ya da nüfus planlaması amacıyla tıp mesleğini icraya hukuken yetkili kişiler tarafından tıp bilimince kabul görmüş esaslara uygun olacak şekilde gerçekleştirilen her türlü faaliyet olarak tanımlanabilir8 ${ }^{8}$.

Hasta-hekim ilişkisinin hukuki ve etik çerçevesi, ulusal ve uluslararası sözleşmeler, bildirgeler, yasalar, yönetmelikler gibi yazılı metinlerle belirlenmiştir. Yasal olarak hekim sorumluluğundan bahsedilebilmesi için, hekimin fiilinin hukuka aykırı olması, bir zararın oluşması ve meydana gelen zarar ile hekimin kusurlu eylemi arasında nedensellik (illiyet) bağının kurulması gerekmektedir9. Hekimlerin mesleki uygulamaları ile ilgili çok sayıda yasal düzenleme mevcut olsa da Türk ceza ve medeni hukuk mevzuatında hekimlerin hukuki sorumluluklarını düzenleyen özel bir hüküm bulunmamaktadır. Hatalı tıbbi uygulama ile suçlanan hekimler; ceza davası, hukuk (tazminat) davası, meslek kuruluşu tarafından yürütülen disiplin işlemleri ve idari soruşturma gibi çeşitli hukuksal süreçlerle karşı karşıya kalabilmektedir ${ }^{10}$.

Çalışmamızda hatalı tıbbi uygulama iddiası nedeniyle görüşümüze başvurulan dosyaların yıllara göre dağılımı incelendiğinde, hemen hemen sürekli bir artış periyodunda olduğu, 2018 yılında neredeyse 2016 ve 2017 yıllarında başvurulan dosya sayısından daha fazla olduğu tespit edilmiştir. $\mathrm{Bu}$ bulgumuz diğer çalışmalarla da uyumluluk göstermektedir. 1990-2000 yılları arasında hatalı tıbbi uygulama iddiası nedeniyle Adli Tıp Kurumundan (ATK) görüş istenen olgu sayısı 653 iken 11, sadece 2009 yılında ATK 3. Adli Tıp İhtisas Kurulu'ndan görüş istenen olgu sayısının 707 olduğu, 2012-2014 yılları arasında ise ATK 1. İhtisas Kurulu'ndan görüş istenen olgu sayısının 1320 olduğu bildirilmiştir ${ }^{12}$. Bu dosya sayılarında artış olması nedeniyle ATK bünyesinde 7 ve 8 . İhtisas kurulları açılmıştır. Amerika Birleşik Devletleri'nde yapılan bir çalışmada 1990 yılında hatalı tıbbi uygulama iddiasıyla açlan dava sayısının 2320 olduğu, 2011 yılında bu sayının 88460'a kadar çıktığı tespit edilmiştir ${ }^{13}$.

Hatalı tıbbi uygulama iddiası ile açılan dava sayılarında ki artışın nedenleri olarak; tıp biliminin ilerlemesiyle birlikte hasta ve hasta yakınlarının sağlı hizmetleri konusunda 
beklentilerinin artmış olması, hatalı tıbbi müdahale ile ilgili olayların sözlü ve yazılı medyaya yansımasıyla insanların bu konudaki farkındalığının artması, malpraktis davalarının bazı avukatlarca özel çalışma alanı olarak seçilmesi, ciddi miktarda tazminat elde etme beklentisi, mevcut yasal düzenlemeler ve sağlık politikaları, sağlık çalışanları ve hasta/hasta yakını arasında iletişim eksiklikleri, tıp eğitiminden kaynaklanan sorunlar ve sağlık çalışanlarının çalışma koşulları gösterilebilir ${ }^{14,15}$.

Hatalı tıbbi uygulama genel olarak tanı hataları, tedavi hataları, koruyucu tedavi hataları ve diğer hatalar olarak sınıflandırılmaktadır. Tanı hataları içerisinde; hastaya yanlış tanı koyulması ya da tanı koymakta gecikme, gerekli tetkiklerin yapılmaması, güncel olmayan tanı yöntemlerinin kullanılması ve tetkiklerin yorumlanmasındaki hatalar yer alırken; tedavi hataları içerisinde cerrahi işlem sırasındaki hatalar, uygun olmayan tedavi, tedavide gecikme, ilaç dozu ve uygulanış metodundaki hatalar yer almaktadir. Profilaktik tedavi uygulamama ya da yanlış uygulama ve tedavi sonrası yetersiz izlem, profilaksi hataları kategorisinde bulunmaktadır. Bunların dışında kalan; ekipmanlardaki eksiklik veya yetersizlikler, sistem, yönetim ve organizasyonla ilgili eksiklik veya yetersizlikler ile iletişim hataları diğer hatalar kategorisinde yer almaktadır ${ }^{16}$.

Hatalı tıbbi uygulama iddiasında bulunulan hekimlerin uzmanlık branşlarına göre dağılımının, bu alanda yapılan farklı çalışmalara göre değişmekle beraber; genel olarak cerrahi branşlarda daha yüksek oranda olduğu bildirilmektedir. Çalışmamızda da hekim branşları dahili ve cerrahi olarak ayrıldığında, \%61,36 oranla cerrahi alan branşında hatalı tıbbi uygulama iddiasıyla başvuru olduğu, tıbbi uygulama hatası olduğu şeklinde görüş bildirilen 4 dosyada ki hekim branşları incelendiğinde, dosyaların 2'sinde Kadın
Doğum, 1'inde Ortopedi, 1'inde Pratisyen hekim branşlarından olduğu görüldü. Şeker'in "Malpraktis Davalarında Aydınlatılmış Onam ile İlgili Yargıtay Kararlarının Değerlendirilmesi" çalışmasında, Yargıtay'a yansıyan davaların uzmanlık alanlarına göre dağılımı değerlendirildiğinde, \%77,6 ile en sık cerrahi branşların dava edildiği, cerrahi branşlar içerisinde ise en sık dava edilen hekimlerin plastik, rekonstruktif ve estetik cerrahi uzmanı olduğu, ikinci sırayı ise genel cerrahi uzmanlarının aldığı görülmüştür ${ }^{17}$. Cerrahi işlemlerin risklerinin daha yüksek olması ve hastaların bu işlem sonrası sağlı beklentilerinin diğer tedavi yöntemlerine göre daha fazla olması nedeniyle diğer branşlara göre şikâyet edilme oranlarının daha yüksek olduğu düşünülmektedir. Le ve ark. cerrahi bölümlere başvuran hastaların diğer hastalara oranla daha ciddi hastalıklara sahip olduğunu, cerrahi tedavi sonrasında fayda görme beklentilerinin daha yüksek olduğunu ve cerrahi müdahalelerin diğer tedavi yollarına daha riskli olduğunu bildirmişlerdir ${ }^{18}$.

Hatalı tıbbi uygulama iddiası bulunan sağlık hizmetinden, görüş için tarafımıza başvuru arasında geçen süre incelendiğinde; mütalaa ile olay arasında ortalama 28 ay süre olduğu, en uzun süre olarak 11 yll sonra görüşümüze başvurulduğu, başvuruyu yapan mercilere göre incelendiğinde ise, bireysel (özel) ve Cumhuriyet Savcılığı başvurularının ortalama 2 yıl içerisinde, mahkeme başvurularının ise ortalama 4 yll içerisinde olduğu tespit edilmiştir. $\mathrm{Bu}$ iddialar hukuk sistemine müracaat ettiklerinde bilirkişi raporlarının oldukça uzun süreler sonra alınması hem bu iddia altında ezilen hekimlerin hem de hatalı uygulama sonucu zarar gören hastaların defalarca dava duruşmalarına gidip gelmek durumunda kalmaları, adalet sisteminin uzun süreli olarak meşgul edilmesi, yargılama sürelerinin uzaması ve adaletin gecikmesine neden olmaktadır. 
Tıbbi müdahale sonrası meydana gelen durumlara göre inceleme yapıldığında, 37 dosyadan 18'inin ölümlü olduğu, ölümlü dosyaların 11'inde otopsi işlemi yapılmamış olduğu, 7 tanesinde ise otopsi işleminin yapılmış olduğu, otopsi işlemi yapılan 7 davadan 6 tanesinde hekim kusuru olmadığı, 1 tanesinde hekim kusuru olduğu, 6 dosyada duyulardan veya organlardan birinin işlevinde sürekli zayıflama ya da yitirilme durumunun meydana gelmiş olduğu, hekim kusuru kararı verilen olgulardan hiçbirinde duyulardan veya organlardan birinin işlevinde sürekli zayıflama ya da yitirilme durumunun meydana gelmemiş olduğu tespit edilmiștir. Hatalı tıbbi uygulama iddiası bulunan ölümlü olguların olduğu dosyalarda otopsi işlemi ile ölüm sebebinin kesin olarak tespit edilmesi hem uygulamanın hatalı olup olmadığı hem de kişinin ölüm sebebinin uygulama ile ilişkili olup olmadığının tespiti açısından oldukça önem taşımaktadır.

Dosya içerisinde aydınlatılmış onam evrakının durumuna göre inceleme yapıldığında, 37 dosyadan 31'inde aydınlatılmış onamla ilgili herhangi bir evrak bulunmadiğı, 5'inde aydınlatılmış onam evrakının bulunduğu, bu onamların uygun olduğu, 1'inde ise aydınlatılmış onam alınmadan işlem gerçekleştirilmiş olduğu tespit edilmiştir. Ulusal mevzuata göre büyük cerrahi işlemlerde yazılı rıza şartı aranmakta olsa da ülkemizde yapılan çalışmalarda, büyük cerrahi işlem yapılacak olan hastaların yarısının fazlasından aydınlatılmış onam alınmadığı bildirilmiştir. Aydın Er ve ark. tarafından yapılan çalışmada; ortopedi hastalarının \%53,5'inin dosyasında imzalı aydınlatılmış onam formu bulunmadığı görülmüşs ${ }^{19}$. Turla ve ark. tarafından yapılan çalışmada; orta-büyük cerrahi işlemler öncesi hekimlerin \%67,1'inin, küçük cerrahi işlem öncesi hekimlerin \%79'unun onam almadıkları görülmüştür ${ }^{20}$. Şeker'in çalışmasında, cerrahi işlemlerde mahkeme dosyasında aydınlatılmış onam mevcut olma oranının \%59,2'de kaldığ 1 görülmüştür ${ }^{17}$. Cerrahi işlemler öncesi aydınlatılmış onam alma oranlarının düşük olmasının nedenleri; hekimler tarafindan aydınlatılmış onamın formalite olarak görülmesi, iş yoğunluğu nedeniyle hekimlerin hastalarını bilgilendirmek için yeterince vakit ayıramamaları, hekimlerin aydınlatılmış onam ile ilgili mevzuata hâkim olmamaları, ileride karşılaşabilecekleri etik ve yasal sorunların farkında olmadıkları șeklinde düşünülmektedir.

Hasta-Hekim ilişkisinde ihlal edildiği iddia edilen yükümlülüklere göre inceleme yapıldı̆̆ında, 37 dosyadan 8 dosyada 'Özen' konusunda, 7 dosyada 'Tanı' konusunda, 1 dosyada 'Tanı ve Özen' konusunda, 3 dosyada 'Tani-Tedavi' konusunda, 15 dosyada 'Tedavi' konusunda, 3 dosyada 'Özen-Tedavi' konularında eksiklik olduğunun iddia edildiği, hasta ve hekim arasında tartışma olup olmadığ incelendiğinde, 37 dosyadan 11 dosyada hastahekim arasında tartışma olduğu, bu 11 dosyadan 10 dosyada hekim kusuru olmadığı, 1 dosyada hekim kusuru olduğu tespit edilmiştir. Hasta-hekim ilişkisi doğası gereği karşıllıklı güven üzerine kurulmaktadır. $\mathrm{Bu}$ güvenin oluşması ise karşılıklı doğru, yeterli ve iyi bir iletişimden geçmektedir. Karşılıklı tartışmanın olduğu tespit edilen 11 dosyadan 10 tanesinde hekim kusuru olmadığı tespit edilmiş, 1 dosyada ise hekim kusuru olduğu kararı verilmiștir. Buradan da görüldüğü üzere karşılıklı ilişkinin sorunlu olması sonucu gereksiz adli girişimlerde bulunulmakta hem hukuk sistemi hem hekim hem hasta ve yakınları bu durumla meşgul olmaktadırlar.

Hatalı tıbbi uygulama olup olmadığı incelendiğinde ise, 37 dosyadan 4 dosyada kusur olduğu, 33 tanesinde kusur olmadığı, kusur olduğu tespit edilen dosyalardan 2 dosyanın Mahkeme, 1 dosyanın bireysel (özel), 1 dosyanın Cumhuriyet Savcllığ tarafından başvurulan dosyalar olduğu görülmüştür. $\mathrm{Bu}$ başvurulardan, 23 dosyanın bireysel başvuru, 8 dosyanın Mahkeme, 5 dosyanın Cumhuriyet 
Savcllığı, 1 dosyanın il sağlık müdürlüğü tarafından görüşümüze başvurulan dosyalar oluşturmaktadır. Görüş bildirdiğimiz dosyaların çok büyük bir kısmında hekim kusuru olmadığı yönünde rapor düzenlemiş olmamızın nedeni, başvuruların çoğunu oluşturan bireysel bașvuru yapılan dosyalarda hekimin kusurlu olduğu görüşüne sahip olabileceğimiz dosyaların tarafımızca kabul edilmemesidir.

\section{SONUÇ}

Hatalı tıbbi uygulama iddiaları gün geçtikçe artmakta hasta veya yakınları istenen sonucun ortaya çıkmadığı durumlarda şikayetçi olmaktadır. Hekimlere yönelik şikayetlerin artmasının defansif tıp uygulamalarını arttırdığı, bunun hem hastanın tanı-tedavisini geciktirdiği hem de sağlık sistemi üzerinde yük oluşturduğu unutulmamalıdır. Hatalı tıbbi uygulama iddialarını en aza indirmek için sağlık çalışanlarının mesleki bilgi ve tecrübelerini geliştirmek dışında iyi bir hekim hasta iletişimi kurmaları gerekmektedir. Ölümün gerçekleștiği olgularda ölüm sebebinin belirlenmesi için otopsi yapılması sağlı çalışanlarının kusurunun olup olmadığını belirlemek konusunda oldukça önemli olduğundan, hatalı tıbbi uygulama şüphesi/şikayeti olan tüm ölüm olgularında otopsi yapılması hatalı tıbbi uygulama varlığının tespiti konusunda oldukça önem arz etmektedir.

Etik Kurul Kararı: Bu çalışma için 22 Ocak 2021 tarih ve 107 Sayılı T.C. Çukurova Üniversitesi Tıp Fakültesi Girişimsel Olmayan Klinik Araştırmalar Etik Kurulu Toplantısında Etik Yönden Uygun olduğuna dair 10 Karar Numarası ile onay alınmıştır.

Çıkar Çatışması Beyanı: Yazarlar çıkar çatışması olmadığını bildirmişlerdir.

Finansal Destek: Bu çalışma herhangi bir fon tarafından desteklenmemiştir.
Declaration of Conflicting Interests: The authors declare that they have no conflict of interest.

Financial Disclosure: No financial support was received.

\section{KAYNAKLAR}

1. Kaya M. Hekimin hastayı aydınlatma yükümlülüğünden kaynaklanan taziminat sorumluluğu. Türkiye Barolar Birliği Dergisi. 2012: 45-82.

2. Altun G, Yorulmaz AC. Yasal değişiklikler sonrası Hekim sorumluluğu ve Malpraktis. Trakya Univ Tip Fak Derg. 2010; 27: 7-12.

3. Barlıoğlu HC: Defansif tıp unsuru olarak tıbbi malpraktis: Seçkin Yayıncllık; 2018.

4. Polat 0, Pakiş I. Tıbbi uygulama hatalarında hekim sorumluluğu. Acıbadem Üniversitesi Sağlı Bilimleri Dergisi. 2011: 119-25.

5. Hakeri H. Tıp hukukunda malpraktis komplikasyon ayrımı. Bulletin of Thoracic Surgery/Toraks Cerrahisi Bülteni. 2014; 5.

6. Özkara E, Can M. Yargitayda karara bağlanan tıbbi uygulama hatası dosyalarının değerlendirilmesi. Dokuz Eylül Üniversitesi Tıp Fakültesi Dergisi. 2011; 25: 69-76.

7. Özer Ö, Taștan K, Set T, Çayır Y, Şener M. Malpractise. Dicle Medical Journal. 2015; 42: 394-7.

8. Ayan M: Tıbbi müdahalelerden doğan hukuki sorumluluk: Kazancl; 1991.

9. Tuğcu H, Yorulmaz C, Koç S. Hekim sorumluluğu ve tıbbi malpraktis. Birinci Basamakta Adli Tıp kitabı içinde Ed: Koç S, Can M, İstanbul Tabip Odası Yayını, İstanbul. 2010: 9-17.

10. Demir M. Hekimin Sözleşmeden Doğan Sorumluluğu. Ankara Üniversitesi Hukuk Fakültesi Dergisi. 2008; 57: 225-52.

11. Büken E, Büken NÖ, Büken B. Obstetric and gynecologic malpractice in Turkey: incidence, impact, causes and prevention. Journal of clinical forensic medicine. 2004; 11: 233-47.

12. Naziroğlu A: 2012-2014 Yılları Arasında Adli Tıp Kurumu Birinci Adli Tıp İhtisas Kurulu Tarafından Görüş Bildirilen Anestezi Ve Reanimasyon Branşı İle İlgili Tıbbi Uygulama Hatası İddiası Bulunan Olguların Değerlendirilmesi. Uzmanlık Tezi. Adli Tıp Kurumu; 2016.

13. Health UDo, Services H. Health resources and services administration. National Center for Health Workforce Analysis. 2014: 2012-25. 
14. Kocaaslan D, Nihal F. İstanbul tabip odasına yansıyan plastik, rekonstrüktif ve estetik cerrahi alanını ilgilendiren tıbbi uygulama hatası iddialarının medikolegal olarak değerlendirilmesi. 2020.

15. Ertem G, Oksel E, Akbıyık A. Hatalı tıbbi uygulamalar (malpraktis) ile ilgili retrospektif bir inceleme. 2009.

16. Leape LL, Lawthers AG, Brennan TA, Johnson WG. Preventing medical injury. QRB Quality review bulletin. 1993; 19: 144-9.

17. Şeker Z: Malpraktis davalarında aydınlatılmış onam ile ilgili yargıtay kararlarının değerlendirilmesi. Tıpta Uzmanlık. Adana: Çukurova Üniversitesi Tıp Fakültesi; 2020.
18. Li H, Wu X, Sun T et al. Claims, liabilities, injures and compensation payments of medical malpractice litigation cases in China from 1998 to 2011. BMC health services research. 2014; 14: 1-9.

19. Er R, Senses M, Akpinar A. Ortopedide aydınlatılmıs onama ait etik sorunlar (Ethical problems about the informed consent in orthopedics: a sample from Kocaeli). Turkiye Klinikleri J Med Sci. 2011; 31: 455-63.

20. Turla A, Karasslan B, Dabakı Ş. Ondokuz Mayıs Üniversitesi Tıp Fakültesi'nde Görev Yapan Hekimlerin Aydınlatılmış Onam. Konusundaki Bilgi ve Tutumlar "OM Ü Tıp Dergisi. 2004: 57-63. 